\title{
Drought Disaster Risk Adaptation through Ecosystem Services-Based Solutions: Way Forward for South Africa
}

\author{
Israel Ropo Orimoloye *(D), Leocadia Zhou and Ahmed M. Kalumba (D) \\ Risk \& Vulnerability Science Centre, Alice Campus, University of Fort Hare, Alice 5700, South Africa; \\ Lzhou@ufh.ac.za (L.Z.); akalumba@ufh.ac.za (A.M.K.) \\ * Correspondence: orimoloyeisrael@gmail.com
}

Citation: Orimoloye, I.R.; Zhou, L.; Kalumba, A.M. Drought Disaster Risk Adaptation through Ecosystem Services-Based Solutions: Way Forward for South Africa. Sustainability 2021, 13, 4132. https://doi.org/10.3390/su13084132

Academic Editors: Godwell Nhamo, Kaitano Dube, David Chikodzi and Lazarus Chapungu

Received: 23 January 2021

Accepted: 17 February 2021

Published: 8 April 2021

Publisher's Note: MDPI stays neutral with regard to jurisdictional claims in published maps and institutional affiliations.

Copyright: (C) 2021 by the authors. Licensee MDPI, Basel, Switzerland. This article is an open access article distributed under the terms and conditions of the Creative Commons Attribution (CC BY) license (https:/ / creativecommons.org/licenses/by/ $4.0 /)$.

\begin{abstract}
Ecosystem services refer to the direct and indirect benefits to humanity from an ecosystem. The ability to spatially incorporate multiple biophysical environments is crucial to ecosystem services, thus promoting cooperation between science and policy in seeking solutions to global challenges, including drought disasters. Therefore, understanding ecosystem services, for instance, from forest/vegetation in view of contributing to drought disaster risk adaptation is critical to human-nature interactions and proper sustainable conservation thereof. No known study has been done on ecosystem services and their contributions to drought management or other climate adaptation in South Africa. This study aimed at quantifying drought disaster risk adaptation based on ecosystem services in South Africa. It was identified that ecosystem services to society have been directly affected by anthropogenic and natural phenomena, thereby influencing drought severity and its impacts. These impacts and their associated risks are evident globally, including in South Africa. We found out that ecosystems in South Africa have been affected and extremely vulnerable to recurrent natural disasters, such as droughts. To achieve long-term solutions to such drought-related risks and challenges, feedback mechanisms between human-natural and related factors and ecosystem services-based drought adaptation need to be understood and planned. Timely spatiotemporal assessment, planning and management strategies need to be considered to find solutions or ways forward to South Africa in combating drought disasters.
\end{abstract}

Keywords: adaptation; drought disaster risk; ecosystem services; South Africa

\section{Introduction}

Without a doubt, societies need water, however, water scarcity and quality due to climate change and other factors are threatening food security and other water-reliant sectors around the world [1-3]. Adapting to climate change helps reduce the risk of water-related disasters such as droughts and floods. Drought is a natural occurrence that often affects humans, the environment, the economy and ecosystems. Prolonged droughts decrease food production and the availability of water and contribute to severe environmental destruction and loss of life. Droughts have a detrimental effect on ecosystems' functions, reduce social, political, and economic stability, and can increase vulnerability to other natural disasters such as droughts, heatwaves and floods [4]. In large parts of Africa and in America, as well as in Southern, Central and Eastern Europe, the Middle East, Australia and Southeast Asia, climate change is expected to increase the frequency and severity of droughts [5-7]. The population of the most vulnerable regions, particularly the poorer areas where land and water supplies are already limited, need to be better prepared for potential droughts by reducing and adjusting risks and increasing resistance to droughts. The way drought is monitored and managed has been modified in studies and numerous recent international and regional initiatives [2,4]. Historically, drought has been regarded as a natural hazard that society reacts to with a reactive approach. This hazard management approach only discusses the consequences of drought. This strategy has proven to be less efficient because 
it produces a culture of dependence and provides little incentives to improve how land and water supplies are monitored to minimize future impacts of drought [8].

Today, drought is seen more frequently as a natural phenomenon requiring society to take a pro-active approach to preparedness to reduce social vulnerability and improve drought disaster adaptation $[9,10]$. As with any natural disaster, drought management should not be based exclusively on disaster management but must include the entire disaster management cycle. Better management of land and water supplies is the objective of a pro-active approach to rising drought resistance. Preventing land loss and maintaining and restoring natural resources and ecosystem services through land regeneration, ecological conservation and water redistribution to environmental flows would improve ecological, economic and social structures against more extreme drought impacts and enhance their capacity to recover from disasters [11,12]. Ecosystem services refer to the various and varied benefits that the natural environment and healthy ecosystems offer to humans. Many other ecological benefits are offered by nature-based drought management strategies, including minimizing threats from other natural disasters as well as mitigating and adapting to climate change, including drought events. Improved drought monitoring, forecasting and early warning systems, as well as assessments of drought vulnerability and effects for populations at risk, are also included in constructive ways to reduce drought risks.

Sub-Saharan African (SSA) rain-fed agriculture, including South Africa, provides important yet highly climate-dependent livelihood sources. Recurring dry spells and droughts can have several impacts on the agro-ecosystems of the region, adversely impacting local social-ecological systems. Droughts damage crops and livestock and influence a range of ecosystem services and degrade natural resources $[13,14]$. However, ecosystems may also frequently be important agents for adaptation to drought risk, mitigation, and resilient livelihoods. Ecosystem-based approach reduces the impacts of drought while offering several co-benefits. These co-benefits lead to poverty alleviation and sustainable development, food security, protection of biodiversity, carbon sequestration and resilience to livelihoods, as well as strategies for adaptation. Ecosystem-based solutions have always been essential in reducing climate change impact including drought impact [14,15]. Using ecosystem services in environmental or disaster planning can be traced at least to the ecosystem-based management's development which will help in sustaining its functions. The aim of the study is to explore drought disaster risk adaptation using ecosystem services in South Africa based on literature and suggest possible ways to use and manage it effectively.

\section{Methodology}

Relevant research papers consisting of peer-reviewed journal articles were reviewed. The selected papers were obtained from Web of Science scientific databases using a search title-specific algorithm on 1 January 2021. In total, 12 papers were acquired; after reading through their titles and abstracts, however, it was noted that all of them dealt with topics beyond the scope of this review. For instance, a study focused on the effects of droughts on vegetation conditions and ecosystem service [16]. Another study dealt with the short-term effects of crop diversity on resilience and ecosystem service provision under drought [17]. None of the studies worked on drought risk adaptation or mitigation through ecosystem services.

Primarily, the search term was drought and ecosystem services and it was refined by excluding the publication year 2021 and document types: (article) timespan; all years' indexes: SCI-expanded, SSCI, A\&HCI, CPCI-S, CPCI-SSH, BKCI-S, BKCI-SSH, ESCI, CCREXPANDED, IC. The title-specific algorithm only retrieved primary articles and excluded other document types for the primary reasons that they were pre-article items that could be published in other forms or post-publication synthesis of primary articles. Manual validation of the total articles was further done to ascertain the specificity and efficiency of the search algorithm in recovering the subject keyword from the database. Overall, the dataset contained 12 relevant articles and was downloaded as BibTeX file. Furthermore, 
records on drought events in South Africa between 1964 and 2019 were retrieved on the 28th of December 2020 from the EM-DAT database to identify its occurrences and the potential losses associated with drought disaster in South Africa. The database is compiled from many outlets, including the United Nations, government and non-government organizations, insurance firms, research institutions and press agencies (Table 1). A specific disaster would only be included in the EM-DAT database in most situations if at least two outlets confirm the disaster's occurrence regarding deaths and/or affected groups of people or persons. 
Table 1. Drought disaster events and damages caused in South Africa from 1964 to 2019 (Source: EM-DAT database).

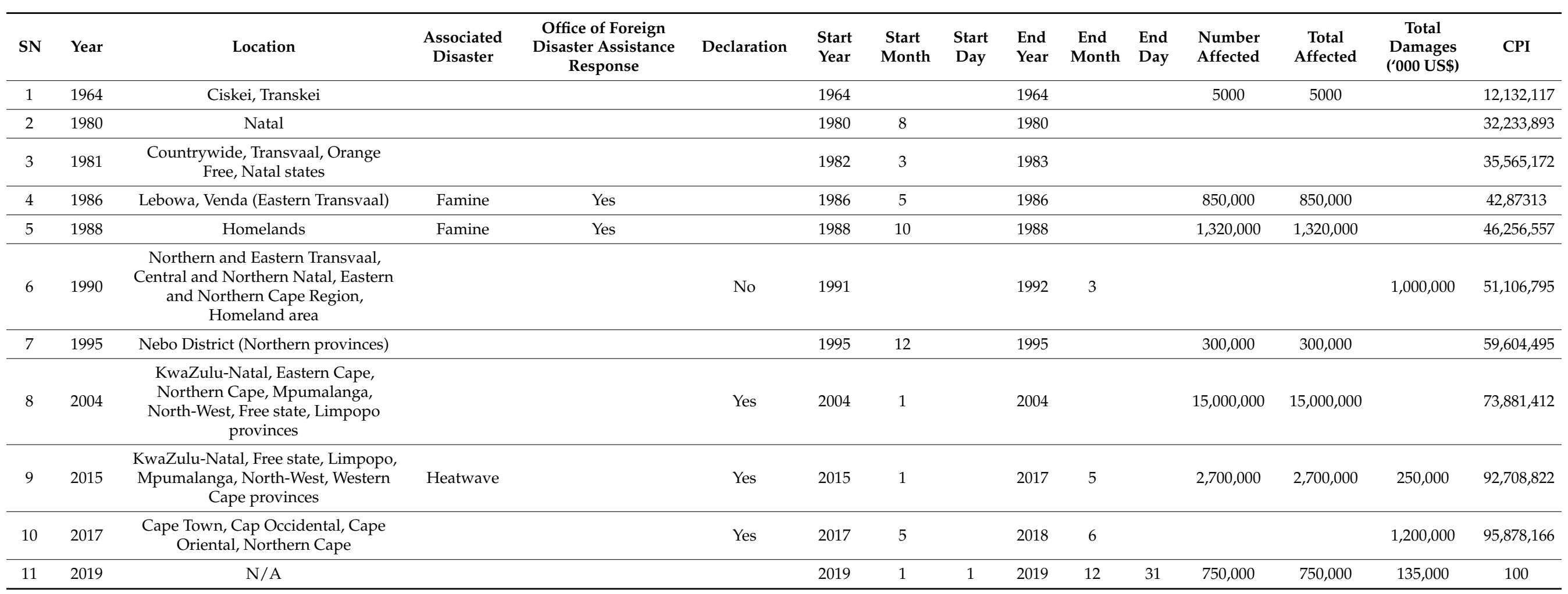




\section{Result and Discussion}

The information in Figure 1 summarized the evolution of drought and ecosystem services-related research in a wordcloud. Wordcloud was used on the titles of the published papers selected based on the search words. It indicates the predominant word or term used in the drought coupled with ecosystem services research. It is easy to distinguish and figure out different areas of associations and prominent terms within the wordcloud [18]. This was done to know the research trends in the drought and ecosystem services research field and to identify the most emerging and frequent keywords used in the field. For instance, the relevant words or frequently mentioned words in the drought and ecosystem services studies are ecosystems which were mentioned 12 times in the paper's title while service was mentioned 10 times, drought (7 times), effects (4 times), drought-induced and losses were mentioned 3 times each during the survey period. These connote that ecosystem functioning is prominent in climate-related risk mitigation and adaptation strategies studies.

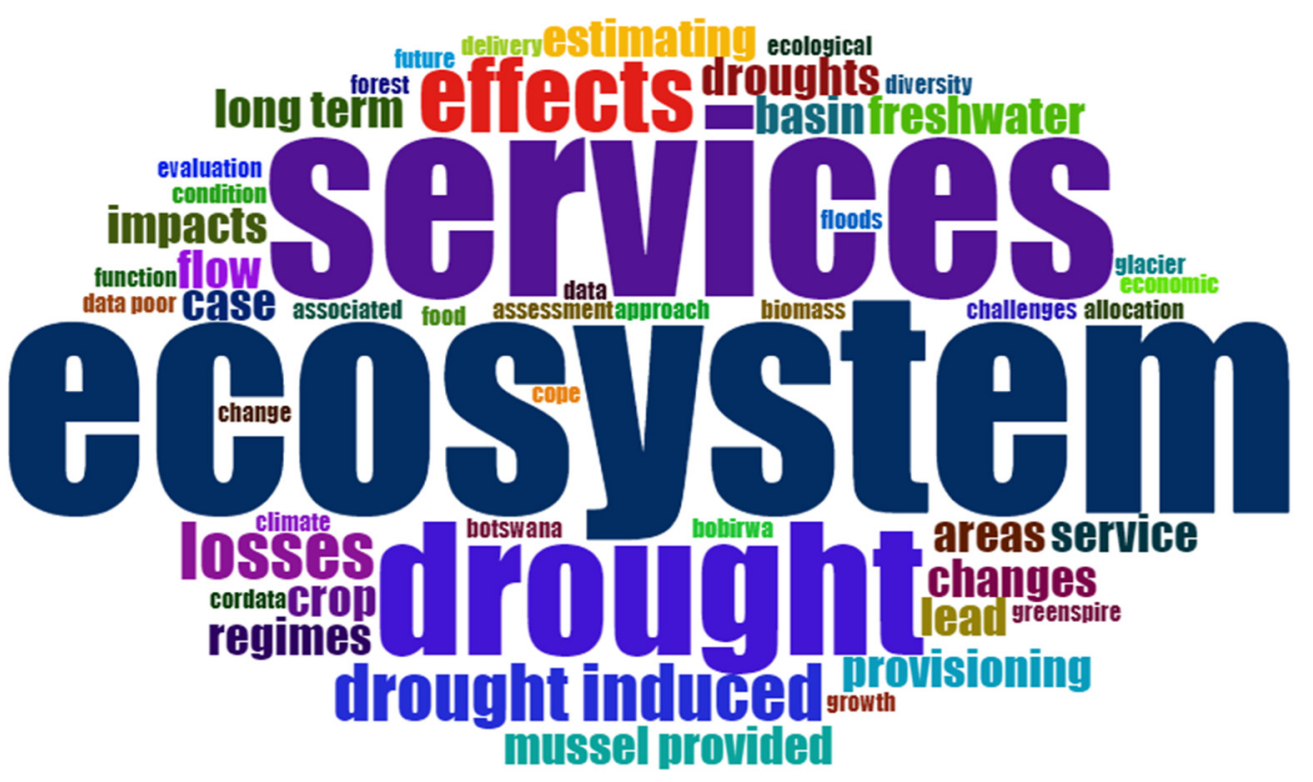

Figure 1. Wordcloud on drought events and ecosystem services research.

This paper offers an overview of approaches to drought risk adaptation in South Africa in the light of ecosystem services-based disaster risk adaptation, based on available literature. Using selected parameters, the analysis identified a few types of approaches that improve ecosystem functionality and provide significant environmental and socioeconomic benefits, thereby helping to adjust to drought effects. However, out of 12 researches on drought and ecosystem services-related studies, only one study was done on Limpopo Basin and Botswana, which basically focused on the effects of droughts on vegetation and ecosystem services and its relevance to climate change adaptation including drought events [16]. In order to successfully incorporate these approaches into ecosystem services-based adaptation programs and complement them with more conventional drought disaster risk mitigation and management strategies, more information on these approaches is required. One of the best ways to assess ecosystem services functioning and their status is through remotely-sensed data that are timely and adequate. More so, drought disaster risk mitigation and management strategies will be more achievable when supported by remote-sensing information for monitoring natural vegetation and other ecosystem functioning [7].

\section{Drought Disaster Events in South Africa between 1964 and 2019}

Drought disaster events were explored in this study to identify the affected years and regions in South Africa. In the year 2017, several areas in South Africa witnessed drought 
disasters. This includes Cape Town, Cape Occidental, Cape Oriental, and North Cape. The drought occurrences lasted for more than a year from March 2017 to June 2018 and drought was declared a disaster in the affected areas with accumulated losses of about $\$ 1.2$ million [19]. More so, the information in Table 1 showed that South Africa witnessed intense drought events with about $\$ 1$ million losses as a result of the drought occurrence. These drought episodes lasted for more than a year from 1991 to 1992 which led to losses in the affected areas, including Northern and Eastern Transvaal, Central and Northern Natal, Eastern and Northern Cape Region, and Homeland area (Table 1). The third most affected year during the same period was 2015; the affected areas including KwaZulu-Natal, Free State, Limpopo, Mpumalanga, North-West, and Western Cape Provinces causing about $\$ 250,000$ damages across the regions [19].

There are 11 major drought events recorded in South Africa as presented in Table 1. Several areas in the country observed severe drought episodes with different damage levels. Unfortunately, out of these major drought events that occurred, the affected regions only received Office of Foreign Disaster Assistance (OFDA) response for the years of 1986 and 1988 , where 850,000 and 1,320,000 people were affected during the period. While other areas and years that were most affected did not receive OFDA response, there should be other strategies in combating drought disasters, which is crucial. One strategy that can be regionally or locally instituted is drought disaster adaptation or mitigation since most affected areas and persons were unable to receive relief from OFDA or other agencies. More efficiently, utilizing ecosystem services can stabilize or reduce water demand, and minimize environmental impacts and costs associated with drought disaster by developing new adaptation strategies [20-22]. Drought and water conservation plans including ecosystem services and requirements governing water conservation as well as drought contingency for public water suppliers should be prioritized through restrictions on water use, droughtrelated risk adaptation, special water tariffs, or low-value reduction uses [23,24]. More so, as the social impact of the drought is typically the manifestation of prolonged water scarcity issues, the adapted strategy should also consider the socio-economic dynamics.

\section{Human Activities and Ecosystem Service Issues in South Africa}

The differences between the capacity of ecosystems to provide services and human needs are increasingly widening because of the rapid growth of the population. To meet the needs of social growth, natural, quasi or regulated ecosystems have been able to provide ecosystem services. Ecosystem services are influenced by a variety of factors, including natural drivers: climate (rainfall, temperature, radiation, wind speed and humidity), soil, topography, rivers, land cover and anthropogenic drivers: demographic, economic, socio-political, science and technical, cultural and religious drivers. Natural factors can be measured, but not controlled; anthropogenic factors can be evaluated and controlled elsewhere. The consequences of human activity on ecosystem services are most clearly demonstrated [25-27]. Ecosystem services for natural, quasi or regulated habitats should be provided to meet the needs of social growth. However, because of the rapid growth of the economy and population, existing disparities between ecosystems' capacity to provide services and human needs are also worsening. Studies by Daily and Manson [28] and Dalton [29] opined that, for over the past 50 years, $60 \%$ of global ecosystem resources have been depleted by the rise in the global population and economic development. These human-ecosystem relationships have been governed by the use of natural resources, environmental management policies and other drivers. However, in terms of their effect on ecosystem services and human ecosystem relationships, guided dynamics have been under evaluated [25].

As documented in earlier studies, natural and anthropogenic drivers have been tested by many scholars over Mondego Basin, Portugal and Loess Plateau, China [30,31]. For instance, Pinto et al. [30] found that natural drivers including invasions of species that may have interfered with the system's legitimacy, and evaluation of exotic species can also be affected by current climate change. Surrounding landscape heterogeneity has influenced 
soil ecosystem services, implying soils in heterogeneous environments are less productive and thus have lower yields [32]. The magnitude and the currently estimated reductions in ecosystem services in South Africa due to invasive alien plants and environmental changes may also have a significant effect on the dynamics of land-use [33-35]. Forest/vegetation growth depends on local conditions, such as the slopes and climatic conditions. Farm land-use may also directly have been influenced by topographic uncertainty. In addition, specialized and complex machinery is required to cultivate steep and specific slopes.

There are four major ways that human activity threatens ecosystems globally, including in South Africa: pollution, habitat destruction, overexploitation, and introduction of invasive species. These factors can hinder ecosystem functioning, especially in combating drought-related disasters in any affected regions of South Africa. Overexploitation is a major challenge to natural ecosystems, including ecosystem services [36]. This factor is the consumption of a natural resource at a rate greater than what natural resources can sustain [37-39]. The overhunting of animals is one of the clearest examples of overexploitation, but other forms unfold (Table 2). Land degradation is human-induced changes that affect the capacity of the land and its features to sustain life as well as combating climate disasters such as drought events [38]. The soil benefits from deforestation and overgrazing and leads to a surplus of sustainable yield.

Table 2. Human activity threats to ecosystem services.

\begin{tabular}{|c|c|c|c|}
\hline No. & $\begin{array}{l}\text { Human Activity Threats } \\
\text { to Ecosystem Services }\end{array}$ & Major Findings & References \\
\hline 1 & Overexploitation & $\begin{array}{l}\text { Intensified natural resource exploitation and intensive grazing influence the } \\
\text { ecosystem services, including natural vegetation and other environmental } \\
\text { components that are crucial in combating drought disaster. Natural resource } \\
\text { conservation (preventing misuse and moderating excess extraction and trade) } \\
\text { and preservation of natural grassland resources have been described to be more } \\
\text { beneficial in ecosystem services, especially in climate-related adaptation, } \\
\text { including drought events. }\end{array}$ & {$[40,41]$} \\
\hline 2 & $\begin{array}{l}\text { Pollution and ecosystem } \\
\text { services }\end{array}$ & $\begin{array}{l}\text { It has been identified that urban pollutants can degrade and inhibit ecological } \\
\text { functions and processes. Human activities, including urbanization, can have } \\
\text { significant impacts on biodiversity and the ecosystem. Population growth, } \\
\text { increased industry and commercialization, and expanded provision for new } \\
\text { housing and transport contribute to the increasing extent of pollution. Air } \\
\text { pollution is one of the main environmental risks for human and environmental } \\
\text { health globally. Maintaining and developing green areas can be part of an } \\
\text { integrative strategy to help improve air quality in cities in combating } \\
\text { drought-related issues. Greening areas and forests can remove significant } \\
\text { amounts of pollutants, increasing environmental quality and vegetation } \\
\text { abundance, which is crucial to drought adaptation and mitigation. }\end{array}$ & [42-44] \\
\hline 3 & $\begin{array}{l}\text { Habitat destruction and } \\
\text { ecosystem services }\end{array}$ & $\begin{array}{l}\text { Studies have shown that increases in natural habitat alteration will lead to } \\
\text { reductions in ecosystem functioning and, hence, in providing services including } \\
\text { climate-related risk adaptation. The Fifth Assessment Report (2014) of the } \\
\text { Intergovernmental Panel on Climate Change suggests that ecosystems' } \\
\text { adaptation options may be more limited than for human systems and that } \\
\text { depletion and destruction to both ecosystems and ecosystem services may } \\
\text { therefore be expected. Ecosystem resources enable the functioning of the } \\
\text { ecosystem, including natural environments, such as drought events. Therefore, } \\
\text { better monitoring of habitat loss and disruption to ecosystem resources } \\
\text { is important. }\end{array}$ & [45-47] \\
\hline
\end{tabular}


Table 2. Cont.

\begin{tabular}{|c|c|c|c|}
\hline No. & $\begin{array}{l}\text { Human Activity Threats } \\
\text { to Ecosystem Services }\end{array}$ & Major Findings & References \\
\hline 4 & $\begin{array}{l}\text { Introduction of invasive } \\
\text { species and ecosystem } \\
\text { services }\end{array}$ & $\begin{array}{l}\text { Adaptation to drought disasters by ecosystem services can be effectively } \\
\text { accomplished if xeromorphic characteristics can be developed by plants or } \\
\text { vegetation in arid lands such as South Africa to minimize transpiration under } \\
\text { drought stress. Therefore, it is important to understand the impact of frequent } \\
\text { drought stress on plant biochemical and physiological processes as well as on } \\
\text { the population and/or community of plants in a specific ecosystem. Severe } \\
\text { environmental conditions can induce intriguing adaptations in plants that } \\
\text { enable them to survive and reproduce, despite the negative aspects of such } \\
\text { modifications. These adaptations can lead to the emergence in a given } \\
\text { ecosystem of a new functional group or serve as an essential instrument for } \\
\text { improving agricultural practices and drought disaster risk adaptation. }\end{array}$ & {$[48,49]$} \\
\hline 5 & Deforestation & $\begin{array}{l}\text { The loss of healthy vegetation/forests will degrade key ecosystem resources, } \\
\text { such as drought mitigation and adaptation, biomass and soil carbon storage, } \\
\text { water balance and river flow control, regional climate pattern modulation, and } \\
\text { infectious disease improvement. }\end{array}$ & {$[50,51]$} \\
\hline
\end{tabular}

In ecosystem service processes, sometimes, invasive species are brought on by transporting species either intentionally or accidentally from other world areas. This can be devastating to existing species as invasive species are introduced on a time scale much more quickly than typically would happen with evolution over longer time periods $[52,53]$. This may involve outcompeting indigenous species in the environment, contributing to the decline or extinction of local species, especially those that are very crucial to ecosystem service, and overpopulation as there may be no predators in this new ecosystem for these invasive species (Table 2). They can also be a major economic cost and influence drought episodes [52-54]. By disrupting or replacing natural vegetation resources, invasive species may alter the ecosystem services $[55,56]$. Invasive species can also provide wildlife with little to no food or energy sources [57]. The abundance or variety of species that are critical habitats for animals or for restoring the degraded natural vegetation may also be altered by invasive species $[58,59]$. Drought disaster adaptation through ecosystem services can be realized efficiently if plants or vegetation in the arid land such as South Africa can develop xeromorphic traits to reduce transpiration under drought stress [48,60]. Reduction in transpiration under drought event conditions can also be achieved through leaf shedding as well as proper forest management and planning [61,62].

The bulk of African vegetation/forested areas are located in the Central African countries (37\%) and Southern Africa (28\%), including South Africa. Forest and vegetation are very crucial ecosystems and their functioning, especially in combating climate-related disasters, including drought episodes [63,64]. In South Africa between 2001 and 2019, about $0.80 \%$ of tree cover loss occurred in areas where the dominant drivers of loss resulted in deforestation [65]. South Africa lost 10.3 Kha of the arid primary forest from 2002 to 2019, accounting for 0.77 per cent of its overall loss of tree cover at the same time. In this time, the total area of humid primary forests in South Africa decreased by 8.3 per cent (Figure 2). Vegetation or forest cover is of tremendous importance but is under extreme pressure to harvest various timber and non-timber forest products for sustainable livelihoods and to clean up agricultural production and infrastructure $[66,67]$. More so, this natural asset is facing other environmental stressors such as climate change and degradation. Most information deals with the negative aspects of vegetation cover loss through erosion and deforestation (Table 2). However, more evidence is available on other aspects of forest cover changes, including forest gains, as well as positive forest management issues [68]. There is little information available on forest productivity appraisal and stand dynamics (regrow, growth and mortality). Deforestation is one of the biggest issues of forest/vegetation in South Africa and this has affected ecosystem and nature-based drought adaptation and mitigation plans $[69,70]$. No study has been done on forest/vegetation degradation in 
line with drought or other climate adaptation in South Africa. This development calls for innovative and timely forest and vegetation assessment techniques and its role in ecosystem functioning. While in most areas, vegetation degradation has reached a disaster level where entire systems are collapsing. It is important to examine some of the effects of existing forest/vegetation depletion and to identify some of the potential repercussions of forest or vegetation loss especially in line with the role of ecosystem services in the amelioration of drought events. The continuing loss of natural vegetation could make human and environmental health increasingly vulnerable to ecological issues in the future $[44,71]$. The most immediate effect of deforestation is the loss of ecosystem services offered by tropical rainforests and associated habitats at the local level. Such natural assets provide vital services to humans, such as erosion prevention, drought mitigation, flood control, water filtration, conservation of fisheries, and pollination, which are especially important for the world's poorest people who depend on natural resources for their daily survival. The supply of natural resources such as timber, medicinal plants, nuts and fruits, and game is also decreased by forest destruction in South Africa [72,73]. Deforestation of forests may have a larger effect over the long term, impacting the global environment, drought events, and biodiversity. It is more possible to predict and measure these changes from local effects since they take place over a longer time scale and can be difficult to quantify.
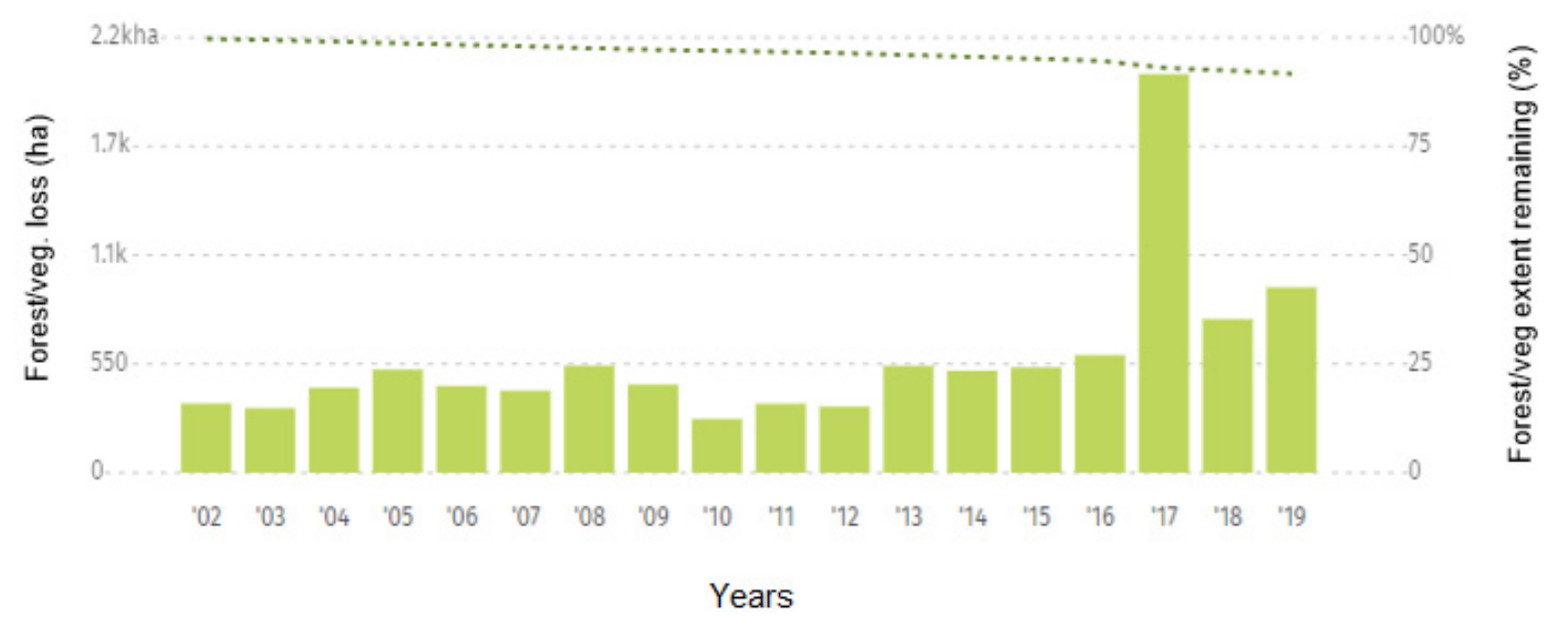

Figure 2. Primary forest/vegetation loss in South Africa between 2002 and 2019 (adapted from the source: Forest global watch, https:/ / www.globalforestwatch.org/dashboards/country/ZAF/ (accessed on 5 January 2021)).

\section{Ecosystem Services Approach to Drought-Related Risk Adaptation in South Africa}

Ecosystem services related to drought are essential for human well-being and environmental functions. In addition to human sustenance, water and drought-based ecosystem services contribute to a multitude of economic sectors, including agriculture, industry and tourism $[74,75]$. Therefore, variability or water scarcity and quality is driven by human activities, including modification of natural environment [76,77], affecting societal health and economy, including drought risks and associated regulating ecosystem services. Climaterelated disasters, such as droughts, are typically analyzed in separate hydrological and climatological approaches, reflecting their distinct underlying processes and causes. For successful planning strategies, however, spatial assessments of such risks should consider the various type of hazards, through a multi-hazard or multi-risk approach considering all spatial levels especially from local to national levels.

Drought frequency cycles have been considered in numerous studies in South Africa. However, these studies focused on the isolated analysis of drought events and occurrence or water scarcity. They did not consider possible benefits of addressing tradeoffs between drought events and ecosystem services-based adaptation, or combined ecosystem service-based risk-adaptation practices and techniques that may reduce drought disaster risks. Ecosystem service-based adaptation measures and their spatial locations should 
be considered and accounted for as much as they can; for instance, vegetation health, water harvesting and reducing peak flows while the areas involved are still functionally in use also for other purposes $[30,78]$. Using such nature-based solutions, their possible multi-functionality needs to be quantified in order to optimize their potential benefits for human well-being and the environment [79]. For instance, measures for water harvesting can be developed to satisfy a dual purpose of drought amelioration and flood prevention in addition to water harvesting. Such dual/multi-functional measures may range from the local and regional scale (e.g., green infrastructure, such as green roofs, green walls, rain gardens) $[79,80]$ to the whole catchment scale (e.g., using natural and constructed wetlands for flood control) [80,81]. More specifically, the South African nature-based solutions include, for example, the use of grass strips for trapping sediments in the country's arid region, restoration of mangroves in the coastal areas, protection of water sources and enhancing water availability from Lesotho by providing more watering points in national parks and community areas, as well as pioneering a climate-resilient marine protected area management in Amathole Marine Protected Area, Table Mountain National Park and Namaqua Fossil Forest Marine Protected Area in Namaqualand, among other important nature reserved in South Africa.

Applying such nature-based solutions can offer significant potential for drought disaster risk reduction; adaptation of this potential requires enhanced planning, implementation and assessment efforts for integrated land and water management $[30,78,82]$, and analysis and decision support systems that can relatively simply and transparently account for human-environment interactions [79]. Possible multi-functionality solutions, such as in drought risk adaptation and mitigation, as well as other environmental stressors such as $\mathrm{CO} 2$-emissions and energy-use management, are very important [83,84]. An ecosystem services-based solution approach may also help South Africa make urban areas and human settlements more inclusive, resilient, sustainable, and safe, thus supporting governments to reach the United Nations Sustainable Development Goal (SDGs) $[85,86]$. More so, these solutions may further assist the country and its surrounding nations to reach other SDGs $(13,15$ and 17), which includes protecting, restoring and promoting sustainable use of terrestrial ecosystems, halting and reversing land degradation, and mitigating biodiversity loss; reducing climate change and its potential impacts, and strengthening means to implement and revitalize the global partnership for sustainable development. In addition, consideration of ecosystem-based solutions in South Africa may also indirectly support food security and sustainable agriculture, and economic growth in the region. Another way of strengthening ecosystem services-based adaptation is through payment for ecosystem services which is an essential aspect of ecosystem-based adaptation. The principle of ecosystem service payments has recently emerged as a promising method to improve or maintain the provision of ecosystem services $[87,88]$.

Besides, considering the ecosystem-based solutions' potential advantages and benefits for drought risk adaptation in South Africa, it is equally important to reflect on the challenges and opportunities for social incorporation of best management practices, and policy and regulatory mechanisms. This should be done in collaboration with stakeholders to drive the implementation of such solutions and practices. The need for space to accommodate such solutions is a huge impediment to introducing, for example, blue and green infrastructure as part of ecosystem-based solutions. Suggesting new land for nature or ecosystem-based solutions can conflict with established land-uses, raising issues relating to land-use planning, land ownership and sharing of benefits. Multi-functionality, i.e., integrating primary ecosystem solution roles, e.g., for water preservation and purification, with other advantages such as recreation and biodiversity conservation, may overcome these challenges to some extent [7]. Gray infrastructures can also be designed to assist in minimizing and managing land requirements, and simultaneously improving water supply and human use as well as water-related sectors [89]. In general, ecosystem-based solutions need new protocols for preparation, implementation and maintenance $[11,90]$ and it is important to recognize the barriers and opportunities of these new criteria to address 
the former and to realize the latter in order to achieve long-term sustainable drought risk adaptation and mitigation solutions.

\section{Summary and Conclusions}

Standardization of the management of ecosystem resources in South Africa is in its inception or yet to exist. At present, by determining congruence with biodiversity, spatial planning and assessment of ecosystem services are often linked with biodiversity. However, ecosystem services deserve to be monitored and protected on their own by means of conservation initiatives explicitly planned for sustainable derived services. It has been identified that the increased frequency and severity of droughts is diminishing natural vegetation, crop productivity and several provisioning ecosystem services through moisture stress and drought-induced agricultural expansions as well as other human activities. There is an urgent need for assessment and proper management of ecosystems, especially natural vegetation in South Africa, to improve natural environment productivity and reduce drought-induced impacts and address vegetation/forest conversion to other artificial purposes.

One of the fast-developing regions in Africa is South Africa and, therefore, the balance between too little water (drought) for millions of people and the environment is a matter of life and death, which needs constant monitoring and efficient usage to ensure ecosystem sustainability. This is because ecosystems are forced to their limits as population centres grow and become more down-converted with rural landscapes. Therefore, the development of appropriate approaches and tools for evaluating and finding sustainable strategies to adapt or mitigate drought-related disasters is critically important. This includes a deeper understanding of input from increased population and related patterns of land-use and ecosystem changes, as well as the combination of persistent climate changes using satellite information for spatiotemporal appraisal. More so, opportunities for vulnerable urbanizing regions to employ ecosystem services-based solutions for drought-related risk adaptation and improved climate resilience need to be explored in particular. In turn, such exploration and utilization need improved spatial planning and management strategies that can drive the implementation and maintenance of successful solutions in combating drought disaster in South Africa.

Some of the basic elements and contents of drought disaster risk adaptation plans are: a spatiotemporal appraisal of drought events in South Africa; general basin characteristics under drought conditions; long drought event history in the affected region; characteristics of droughts within the country; drought warning system and implementation; program for adapting and mitigating droughts linked to indicator systems; agencies or group structures of drought management; update and follow-up of drought disaster events; alternative plans for public water supply and payment for ecosystem services. More significantly, drought disaster risk adaptation plans should include quantitative and realistic water conservation goals and a collection of steps prioritized according to their performance and cost of implementation to achieve these targets. To rediscover South Africa, it is indeed important to consider challenges and opportunities for successful solutions focused on ecosystem services, the social incorporation of best management practices for them, and policy and regulatory mechanisms that, in partnership with stakeholders, can influence its implementation.

Author Contributions: Conceptualization, I.R.O. methodology, I.R.O.; software, I.R.O. validation, I.R.O.; formal analysis, I.R.O.; investigation, I.R.O.; data curation, I.R.O.; writing-original draft preparation, I.R.O.; writing-review and editing, I.R.O., L.Z. and A.M.K.; visualization, I.R.O.; supervision, L.Z. and A.M.K.; project administration, L.Z.; funding acquisition, L.Z. All authors have read and agreed to the published version of the manuscript.

Funding: This study received funding from South Africa/Flanders Climate Adaptation Research and Training Partnership (SAF-ADAPT) project.

Institutional Review Board Statement: Not applicable. 
Informed Consent Statement: Not applicable.

Data Availability Statement: Not applicable.

Acknowledgments: Authors thank South Africa/Flanders Climate Adaptation Research and Training Partnership (SAF-ADAPT) project for providing funding support for the study.

Conflicts of Interest: The authors declare no conflict of interest.

\section{References}

1. Schreiner, B.G.; Mungatana, E.D.; Baleta, H. Impacts of Drought Induced Water Shortages in South Africa: Economic Analysis; WRC Report 2604/1; Water Research Commission (WRC): Pretoria, South Africa, 2018.

2. Adedeji, O.; Olusola, A.; James, G.; Shaba, H.A.; Orimoloye, I.R.; Singh, S.K.; Adelabu, S. Early warning systems development for agricultural drought assessment in Nigeria. Environ. Monit. Assess. 2020, 192, 798. [CrossRef]

3. Ekundayo, O.Y.; Okogbue, E.C.; Akinluyi, F.; Kalumba, A.; Orimoloye, I. Spatiotemporal drought assessment using vegetation health index and standardized precipitation index over Sudano-Sahelian region of Nigeria. Afr. Geogr. Rev. 2020, 1-13. [CrossRef]

4. Crossman, N.D. Drought Resilience, Adaptation and Management Policy (DRAMP) Framework Supporting Technical Guidelines; UNCCD: Bonn, Germany, 2018.

5. Dai, A. Drought under global warming: A review. Wiley Interdiscip. Rev. Clim. Chang. 2010, 2, 45-65. [CrossRef]

6. Orimoloye, I. Assessment of the Human Health Implications of Climate Variability in East London, Eastern Cape, South Africa. Ph.D. Thesis, University of Fort Hare, Alice, South Africa, 2018.

7. Orimoloye, I.R.; Mazinyo, S.P.; Nel, W.; Kalumba, A.M. Spatiotemporal monitoring of land surface temperature and es-timated radiation using remote sensing: Human health implications for East London, South Africa. Environ. Earth Sci. 2018, $77,77$. [CrossRef]

8. Wilhite, D.A.; Sivakumar, M.V.; Pulwarty, R.S. Managing drought risk in a changing climate: The role of national drought policy. Weather Clim. Extrem. 2014, 3, 4-13. [CrossRef]

9. UNISDR. Drought_Living with Risk: An Integrated Approach to Reducing Societal Vulnerability to Drought; United Nations International Strategy for Disaster Reduction (UNISDR): Geneva, Switzerland, 2003.

10. King-Okumu, C.; Tsegai, D.; Pandey, R.P.; Rees, G. Less to Lose? Drought Impact and Vulnerability Assessment in Disadvantaged Regions. Water 2020, 12, 1136. [CrossRef]

11. Keesstra, S.; Nunes, J.; Novara, A.; Finger, D.; Avelar, D.; Kalantari, Z.; Cerdà, A. The superior effect of nature based solutions in land management for enhancing ecosystem services. Sci. Total Environ. 2018, 610, 997-1009. [CrossRef] [PubMed]

12. Constant, N.L.; Taylor, P.J. Restoring the forest revives our culture: Ecosystem services and values for ecological restoration across the rural-urban nexus in South Africa. For. Policy Econ. 2020, 118, 102222. [CrossRef]

13. Kloos, J.; Renaud, F.G. Overview of Ecosystem-Based Approaches to Drought Risk Reduction Targeting Small-Scale Farmers in Sub-Saharan Africa. In Advances in Natural and Technological Hazards Research; Springer: Cham, Switzerland, 2016; Volume 42, pp. 199-226.

14. Hagenlocher, M.; Meza, I.; Anderson, C.C.; Min, A.; Renaud, F.G.; Walz, Y.; Siebert, S.; Sebesvari, Z. Drought vulnerability and risk assessments: State of the art, persistent gaps, and research agenda. Environ. Res. Lett. 2019, 14, 083002. [CrossRef]

15. Meza, I.; Siebert, S.; Döll, P.; Kusche, J.; Herbert, C.; Eyshi Rezaei, E.; Nouri, H.; Gerdener, H.; Popat, E.; Frischen, J.; et al. Global-scale drought risk assessment for agricultural systems. Nat. Hazards Earth Syst. Sci. 2020, 20, 695-712. [CrossRef]

16. Mugari, E.; Masundire, H.; Bolaane, M. Effects of Droughts on Vegetation Condition and Ecosystem Service Delivery in Data-Poor Areas: A Case of Bobirwa Sub-District, Limpopo Basin and Botswana. Sustainability 2020, 12, 8185. [CrossRef]

17. Degani, E.; Leigh, S.G.; Barber, H.M.; Jones, H.E.; Lukac, M.; Sutton, P.; Potts, S.G. Crop rotations in a climate change scenario: Short-term effects of crop diversity on resilience and ecosystem service provision under drought. Agric. Ecosyst. Environ. 2019, 285, 106625. [CrossRef]

18. Nyam, Y.S.; Kotir, J.H.; Jordaan, A.J.; Ogundeji, A.A.; Adetoro, A.A.; Orimoloye, I.R. To-wards Understanding and Sustaining Natural Resource Systems through the Systems Perspective: A Systematic Evaluation. Sustainability 2020, 12, 9871. [CrossRef]

19. Guha-Sapir, D.; Below, R.; Hoyois, P. EM-DAT: International Disaster Database; Catholic University of Louvain: Brussels, Belgium, 2015; Volume 27, pp. 57-58.

20. Nelson, E.J.; Kareiva, P.; Ruckelshaus, M.; Arkema, K.; Geller, G.; Girvetz, E.; Goodrich, D.; Matzek, V.; Pinsky, M.; Reid, W.; et al. Climate change's impact on key ecosystem services and the human well-being they support in the US. Front. Ecol. Environ. 2013, 11, 483-893. [CrossRef]

21. Martín, E.G.; Costa, M.M.; Máñez, K.S. An operationalized classification of Nature Based Solutions for water-related hazards: From theory to practice. Ecol. Econ. 2020, 167, 106460. [CrossRef]

22. Seddon, N.; Chausson, A.; Berry, P.; Girardin, C.A.J.; Smith, A.; Turner, B. Understanding the value and limits of nature-based solutions to climate change and other global challenges. Philos. Trans. R. Soc. B Biol. Sci. 2020, 375, 20190120. [CrossRef]

23. Kahil, M.T.; Dinar, A.; Albiac, J. Modeling water scarcity and droughts for policy adaptation to climate change in arid and semiarid regions. J. Hydrol. 2015, 522, 95-109. [CrossRef]

24. Gober, P.; Sampson, D.A.; Quay, R.; White, D.D.; Chow, W.T. Urban adaptation to mega-drought: Anticipatory water modeling, policy, and planning for the urban Southwest. Sustain. Cities Soc. 2016, 27, 497-504. [CrossRef] 
25. Jing, L.; Zhou, Z.X. Natural and human impacts on ecosystem services in Guanzhong-Tianshui economic region of China. Environ. Sci. Pollut. Res. 2016, 23, 6803-6815.

26. Zhang, Y.; Liu, Y.; Zhang, Y.; Liu, Y.; Zhang, G.; Chen, Y. On the spatial relationship between ecosystem services and urbanization: A case study in Wuhan, China. Sci. Total Environ. 2018, 637, 780-790. [CrossRef]

27. Wang, J.; Zhou, W.; Pickett, S.T.; Yu, W.; Li, W. A multiscale analysis of urbanization effects on ecosystem services supply in an urban megaregion. Sci. Total Environ. 2019, 662, 824-833. [CrossRef]

28. Daily, G.C.; Matson, P.A. Ecosystem services: From theory to implementation. Proc. Natl. Acad. Sci. USA 2008, 105, 9455-9456. [CrossRef]

29. Dalton, S.E. Application of the Human Ecosystem Model in Warfare Ecology. In Building Knowledge for Geohazard Assessment and Management in the Caucasus and Other Orogenic Regions; Springer: Dordrecht, The Netherlands, 2011; pp. $245-257$.

30. Pinto, R.; De Jonge, V.N.; Neto, J.M.; Domingos, T.; Marques, J.C.; Patrício, J. Towards a DPSIR driven integration of eco-logical value, water uses and ecosystem services for estuarine systems. Ocean Coast. Manag. 2013, 72, 64-79. [CrossRef]

31. Fu, B.; Wang, S.; Liu, Y.; Liu, J.; Liang, W.; Miao, C. Hydrogeomorphic Ecosystem Responses to Natural and Anthropogenic Changes in the Loess Plateau of China. Annu. Rev. Earth Planet. Sci. 2017, 45, 223-243. [CrossRef]

32. Orimoloye, I.R.; Adigun, A.I. Response of cassava and maize yield to varying spatial scales of rainfall and temperature scenarios in Port Harcourt. Res. J. Environ. Sci. 2017, 11, 137-142.

33. De Lange, W.J.; van Wilgen, B.W. An economic assessment of the contribution of biological control to the man-agement of invasive alien plants and to the protection of ecosystem services in South Africa. Biol. Invasions 2010, 12, 4113-4124. [CrossRef]

34. Beale, C.M.; van Rensberg, S.; Bond, W.J.; Coughenour, M.; Fynn, R.; Gaylard, A.; Grant, R.; Harris, B.; Jones, T.; Mduma, S.; et al. Ten lessons for the conservation of African savannah ecosystems. Biol. Conserv. 2013, 167, 224-232. [CrossRef]

35. Stafford, W.; Birch, C.; Etter, H.; Blanchard, R.; Mudavanhu, S.; Angelstam, P.; Blignaut, J.; Ferreira, L.; Marais, C. The economics of landscape restoration: Benefits of controlling bush encroachment and invasive plant species in South Africa and Namibia. Ecosyst. Serv. 2017, 27, 193-202. [CrossRef]

36. Barbier, E.B. Scarcity and Frontiers: How Economies Have Developed through Natural Resource Exploitation; Cambridge University Press: Cambridge, UK, 2010.

37. Thobejane, R.M. Legal Evaluation of the Effect of Deforestation and Poverty on the Environment with Special Reference to Thogwaneng Village in Limpopo Province. Ph.D. Thesis, University of Limpopo, Turfloop Campus, South Africa, 2009.

38. Mabasa, M.; Makhubele, J. Impact of Deforestation on Sustainable Livelihoods in Low-Resourced Areas of Thulamela Local Municipality: Implications for Practice. J. Hum. Ecol. 2016, 55, 173-182. [CrossRef]

39. Ramatshimbila, T.V. Assessing the Poverty-Environment Nexus in Three Rural South African Villages: Environmental Degradation, Vulnerability and Perceptions. Ph.D. Thesis, Johannesburg Universisty, Johannesburg, South Africa, 2018.

40. Cumming, G.S.; Buerkert, A.; Hoffmann, E.M.; Schlecht, E.; Von Cramon-Taubadel, S.; Tscharntke, T. Implications of agricultural transitions and urbanization for ecosystem services. Nat. Cell Biol. 2014, 515, 50-57. [CrossRef]

41. Dong, X.; Yu, B.; Brown, M.; Zhang, Y.; Kang, M.Y. China (host institution) Beijing 100875 Beijing Normal University College of Resources Science and Technology State Key Laboratory of Earth Surface Processes and Resource Ecology; Ulgiati, S. Environmental and economic consequences of the overexploitation of natural capital and ecosystem services in Xilinguole League, China. Energy Policy 2014, 67, 767-780. [CrossRef]

42. Livesley, S.J.; McPherson, E.G.; Calfapietra, C. The Urban Forest and Ecosystem Services: Impacts on Urban Water, Heat, and Pollution Cycles at the Tree, Street, and City Scale. J. Environ. Qual. 2016, 45, 119-124. [CrossRef] [PubMed]

43. Wade, R. Urban Pollution and Ecosystem Services. Urban Pollut. 2018, 199-209. [CrossRef]

44. De Carvalho, R.M.; Szlafsztein, C.F. Urban vegetation loss and ecosystem services: The influence on climate regulation and noise and air pollution. Environ. Pollut. 2019, 245, 844-852. [CrossRef] [PubMed]

45. Orimoloye, I.R.; Kalumba, A.M.; Mazinyo, S.P.; Nel, W. Geospatial analysis of wetland dynamics: Wetland depletion and biodiversity conservation of Isimangaliso Wetland, South Africa. J. King Saud Univ. Sci. 2020, 32, 90-96. [CrossRef]

46. Dobson, A.; Lodge, D.; Alder, J.; Cumming, G.S.; Keymer, J.; McGlade, J.; Mooney, H.; Rusak, J.A.; Sala, O.; Wolters, V.; et al. Habitat Loss, Trophic Collapse, and the Decline of Ecosystem Services. Ecology 2006, 87, 1915-1924. [CrossRef]

47. Zommers, Z.; van der Geest, K.; De Sherbinin, A.; Kienberger, S.; Roberts, E.; Harootunian, G.; Sitati, A.; James, R. Loss and Damage: The Role of Ecosystem Services; United National Environment Programme: Nairobi, Kenya, 2016.

48. De Micco, V.; Aronne, G. Morpho-anatomical traits for plant adaptation to drought. In Plant Responses to Drought Stress; Springer: Berlin/Heidelberg, Germany, 2012; pp. 37-61.

49. Da Silva, E.C.; De Albuquerque, M.B.; Neto, A.D.D.A.; Junior, C.D.D.S. Drought and Its Consequences to Plants-From Individual to Ecosystem. In Responses of Organisms to Water Stress; IntechOpen: Rijeka, Croatia, 2013; pp. 18-47.

50. Geldenhuys, C.J.; Ham, C.; Ham, H. Sustainable Forest Management in Africa: Some Solutions to Natural Forest Management Problems in Africa; Stellenbosch University: Stellenbosch, South Africa, 2008.

51. Mátyás, C. Ecological Challenges of Climate Change in Europe's Continental, Drought-Threatened Southeast. In Regional Aspects of Climate-Terrestrial-Hydrologic Interactions in Non-boreal Eastern Europe; Springer: Dordrecht, The Netherlands, 2009 ; pp. 35-46.

52. Liu, L.; Piper, B. Predicting the total economic impacts of invasive species: The case of B. rubostriata (red streaked leafhopper). Ecol. Econ. 2016, 128, 139-146. [CrossRef] 
53. Lauber, T.B.; Stedman, R.C.; Connelly, N.A.; Ready, R.C.; Rudstam, L.G.; Poe, G.L. The effects of aquatic invasive species on recreational fishing participation and value in the Great Lakes: Possible future scenarios. J. Great Lakes Res. 2020, 46, 656-665. [CrossRef]

54. Pérez-Méndez, N.; Andersson, G.K.; Requier, F.; Hipólito, J.; Aizen, M.A.; Morales, C.L.; García, N.; Gennari, G.P.; Garibaldi, L.A. The economic cost of losing native pollinator species for orchard production. J. Appl. Ecol. 2020, 57, 599-608. [CrossRef]

55. Gentili, R.; Montagnani, C.; Gilardelli, F.; Guarino, M.F.; Citterio, S. Let native species take their course: Ambrosia artemisiifolia replacement during natural or "artificial" succession. Acta Oecologica 2017, 82, 32-40. [CrossRef]

56. Lazzaro, L.; Bolpagni, R.; Buffa, G.; Gentili, R.; Lonati, M.; Stinca, A.; Acosta, A.T.R.; Adorni, M.; Aleffi, M.; Allegrezza, M.; et al. Impact of invasive alien plants on native plant communities and Natura 2000 habitats: State of the art, gap analysis and perspectives in Italy. J. Environ. Manag. 2020, 274, 111140. [CrossRef]

57. Geesing, D.; Al-Khawlani, A.; Laouali Abba, M. Management of introduced Prosopis species: Can economic exploitation control an invasive species? Unasylva 2004, 217, 289-299.

58. D'Antonio, C.; Meyerson, L.A. Exotic Plant Species as Problems and Solutions in Ecological Restoration: A Synthesis. Restor. Ecol. 2002, 10, 703-713. [CrossRef]

59. Richardson, D.M.; Holmes, P.M.; Esler, K.J.; Galatowitsch, S.M.; Stromberg, J.C.; Kirkman, S.P.; Pyšek, P.; Hobbs, R.J. Riparian vegetation: Degradation, alien plant invasions, and restoration prospects. Divers. Distrib. 2007, 13, 126-139. [CrossRef]

60. Salehi-Lisar, S.Y.; Bakhshayeshan-Agdam, H. Drought stress in plants: Causes, consequences, and tolerance. In Drought Stress Tolerance in Plants; Springer: Cham, Switzerland, 2016; Volume 1, pp. 1-16.

61. Díaz-López, L.; Gimeno, V.; Simón, I.; Martínez, V.; Rodríguez-Ortega, W.M.; García-Sánchez, F. Jatropha curcas seedlings show a water conservation strategy under drought conditions based on decreasing leaf growth and stomatal conductance. Agric. Water Manag. 2012, 105, 48-56. [CrossRef]

62. Domec, J.-C.; King, J.S.; Ward, E.J.; Oishi, A.C.; Palmroth, S.; Radecki, A.; Bell, D.M.; Miao, G.; Gavazzi, M.; Johnson, D.M.; et al. Conversion of natural forests to managed forest plantations decreases tree resistance to prolonged droughts. For. Ecol. Manag. 2015, 355, 58-71. [CrossRef]

63. Omambia, C.S.; Yansheng, G. The cost of climate change in Tanzania: Impacts and adaptations. J. Am. Sci. 2010, 6, 182-196.

64. Musakwa, W. Impacts of Climate Change on Ecosystem Services and Livelihoods within the Great Limpopo Transfrontier Region; University of Johannesburg: Johannesburg, South Africa, 2020; Available online: http:/ /hdl.handle.net/102000/0002 (accessed on 12 January 2021).

65. Allan, J.R.; Venter, O.; Maxwell, S.; Bertzky, B.; Jones, K.; Shi, Y.; Watson, J.E. Recent increases in human pressure and forest loss threaten many Natural World Heritage Sites. Biol. Conserv. 2017, 206, 47-55. [CrossRef]

66. Kleinn, C.; Yang, Y.; Weyerhäuser, H.; Stark, M. The sustainable harvest of non-timber forest products in China. In Strategies to Balance Economic Benefits and Biodiversity Conservation; Sino-German Symposium: Beijing, China, 2006.

67. Melese, S.M. Importance of non-timber forest production in sustainable forest management, and its implication on carbon storage and biodiversity conservation in Ethiopia. Int. J. Biodivers. Conserv. 2016, 8, 269-277.

68. Da Silva, R.F.B.; Millington, J.D.; Moran, E.F.; Batistella, M.; Liu, J. Three decades of land-use and land-cover change in mountain regions of the Brazilian Atlantic Forest. Landsc. Urban Plan. 2020, 204, 103948. [CrossRef]

69. Zerihun, M.F. A Socioeconomic Analysis of Factors that Affect the Adoption of Agroforestry Technologies in the Eastern Cape Province of South Africa. Ph.D. Thesis, Tshwane University of Technology, Pretoria, South Africa, 2014.

70. Zerihun, M.F. Institutional Analysis of Adoption of Agroforestry Practices in the Eastern Cape Province of South Africa. S. Afr. J. Environ. Educ. 2020, 36. [CrossRef]

71. Mariano, D.A.; dos Santos, C.A.; Wardlow, B.D.; Anderson, M.C.; Schiltmeyer, A.V.; Tadesse, T.; Svoboda, M.D. Use of remote sensing indicators to assess effects of drought and human-induced land degradation on eco-system health in Northeastern Brazil. Remote Sens. Environ. 2018, 213, 129-143. [CrossRef]

72. Mangwale, K.; Shackleton, C.M.; Sigwela, A. Changes in forest cover and carbon stocks of the coastal scarp forests of the Wild Coast, South Africa. South. For. J. For. Sci. 2017, 79, 305-315. [CrossRef]

73. Smithwick, E.A. Carbon stocks and biodiversity of coastal lowland forests in South Africa: Implications for aligning sus-tainable development and carbon mitigation initiatives. Carbon Manag. 2019, 10,349-360. [CrossRef]

74. Muyambo, F.; Bahta, Y.T.; Jordaan, A.J. The role of indigenous knowledge in drought risk reduction: A case of communal farmers in South Africa. Jàmbá J. Disaster Risk Stud. 2017, 9. [CrossRef]

75. Mothupi, L.W. Towards the Development of an Integrated Governance Mechanisms for Recurrent Drought in the North West Province, Republic of South Africa. Ph.D. Thesis, North-West University, Vanderbijlpark, South Africa, 2020.

76. Damkjaer, S.; Taylor, R. The measurement of water scarcity: Defining a meaningful indicator. AMBIO 2017, 46, 513-531. [CrossRef] [PubMed]

77. Nkhonjera, G.K. Understanding the impact of climate change on the dwindling water resources of South Africa, focusing mainly on Olifants River basin: A review. Environ. Sci. Policy 2017, 71, 19-29. [CrossRef]

78. Denison, J.A.; Wotshela, L. An Overview of Indigenous, Indigenised and Contemporary Water Harvesting and Conservation Practices in South Africa. Irrig. Drain. 2012, 61, 7-23. [CrossRef]

79. Kalantari, Z.; Ferreira, C.S.S.; Keesstra, S.; Destouni, G. Nature-based solutions for flood-drought risk mitigation in vulnerable urbanizing parts of East-Africa. Curr. Opin. Environ. Sci. Health 2018, 5, 73-78. [CrossRef] 
80. Young, A.F.; Marengo, J.A.; Coelho, J.O.; Scofield, G.B.; de Oliveira Silva, C.C.; Prieto, C.C. The role of nature-based solutions in disaster risk reduction: The decision maker's perspectives on urban resilience in São Paulo state. Int. J. Disaster Risk Reduct. 2019, 39, 101219. [CrossRef]

81. Kalantari, Z.; Cavalli, M.; Cantone, C.; Crema, S.; Destouni, G. Flood probability quantification for road infrastructure: Data-driven spatial-statistical approach and case study applications. Sci. Total Environ. 2017, 581, 386-398. [CrossRef]

82. Kabisch, N.; Frantzeskaki, N.; Pauleit, S.; Naumann, S.; Davis, M.; Artmann, M.; Haase, D.; Knapp, S.; Korn, H.; Stadler, J.; et al. Nature-based solutions to climate change mitigation and adaptation in urban areas: Perspectives on indicators, knowledge gaps, barriers, and opportunities for action. Ecol. Soc. 2016, 21. [CrossRef]

83. Trowbridge, K. Managing $\mathrm{CO}_{2}$ Emissions Regionally Using Geographical Information System (Gis) Spatial Modeling and Pinch Analysis, Southern Illinois University: Carbondale, IL, USA, 2018.

84. Soussana, J.F.; Barioni, L.G.; Ari, T.B.; Conant, R.; Gerber, P.; Havlik, P.; Ickowicz, A.; Howden, M. Managing Grassland Systems in a Changing Climate: The Search for Practical Solutions; New South Wales Department of Primary Industry: Orange, Australia, 2019.

85. Obani, P.; Gupta, J.; Pahl-Wostl, C.; Bhaduri, A. Human Security and Access to Water, Sanitation, and Hygiene: Exploring the Drivers and Nexus. In Handbook on Water Security; Edward Elgar Publishing: Cheltenham, UK, 2016; pp. $201-214$.

86. Davids, R.; Rouget, M.; Boon, R.; Roberts, D. Spatial analyses of threats to ecosystem service hotspots in Greater Durban, South Africa. Peer] 2018, 6, e5723. [CrossRef] [PubMed]

87. Midgley, S.; Chesterman, S.; Hope, E. Payment for Ecosystem Services: A Climate Change Adaptation Strategy for Southern Africa. For the Regional Climate Change Programme for Southern Africa (RCCP), UK Department for International Development (DFID); OneWorld Sustainable Investments: Cape Town, South Africa, 2012.

88. Van de Sand, I. Payments for ecosystem services in the context of adaptation to climate change. Ecol. Soc. 2012, 17. [CrossRef]

89. Richter, B.D.; Mathews, R.; Harrison, D.L.; Wigington, R. Ecologically Sustainable Water Management: Managing River Flows for Ecological Integrity. Ecol. Appl. 2003, 13, 206-224. [CrossRef]

90. Arabameri, A.; Rezaei, K.; Pourghasemi, H.R.; Lee, S.; Yamani, M. GIS-based gully erosion suscep-tibility mapping: A comparison among three data-driven models and AHP knowledge-based technique. Environ. Earth Sci. 2018, 77, 628. [CrossRef] 